\title{
Knud Knudsen and the Question of Purism
}

\author{
Evy Beate Tveter
}

\begin{abstract}
Language purism is often associated with opposition towards foreign linguistic elements, most typically foreign vocabulary. Most definitions therefore include the dichotomy of foreign versus domestic and/or national and/or un-national. This article takes a look at the Norwegian language reformer Knud Knudsen (1812-1895) and his arguments for excluding most (but not all) foreign words. This leads to a specification of the term foreign, and a description of various arguments for categorizing certain elements as unwanted.
\end{abstract}

\section{Keywords}

Knud Knudsen, Norwegian language, purism 
Language purism is often associated with opposition towards foreign linguistic elements, most typically foreign vocabulary. Most definitions therefore include the dichotomy of foreign versus domestic or national versus un-national. George Thomas' book Linguistic Purism is central in this field, and based on a discussion of various definitions Thomas gives a slightly wider definition of purism (I have underlined the parts that makes his definition more inclusive than usual):

Purism is the manifestation of a desire on the part of a speech community (or some section of it) to preserve a language from, or rid it of, putative foreign elements or other elements held to be undesirable (including those originating in dialects, sociolects and styles of the same language). It may be directed at all linguistic levels but primarily the lexicon. Above all, purism is an aspect of the codification, cultivation and planning of standard languages. (Thomas, 1991, p. 12)

Such a wide definition covers most attempts to "cleanse" a language from elements that are unwanted for some reason. However, the definition does not specify what kind of elements that can be considered "foreign" or "un-pure" or why they fall in that category. In this article I will have a look at the Norwegian language reformer Knud Knudsen (1812-1895) and his arguments for excluding most (but not all) foreign words. This leads to a specification of the term foreign, and a description of various arguments for categorizing certain elements as unwanted.

\section{Short background}

In the debate in Norway during the $19^{\text {th }}$ century about what the written language should look like, there are particularly two individuals who function as symbols of two different solutions to this question. One is Ivar Aasen (1813-1896), the founder of the written standard Landsmål (Nynorsk) based upon various Norwegian dialects. The other is the teacher Knud Knudsen who all his life was a very active advocate for keeping, but severely reforming, the Danish written language.

Knud Knudsen is usually described as the antithesis of Ivar Aasen, and they have later been named "fathers" of each of the two written varieties of Norwegian: Bokmål (Knudsen) and Nynorsk (Aasen). There is of course much more to it than this, and linguistic purism is one area where the two of them shared a common interest. The purism of Aasen is well covered (see for example Gerdener, 1986) whereas Knudsen's argumentation and attitude in this respect have not been thoroughly discussed. I will here merely scratch the surface of his vast productions on this topic and look at some central principles on which he builds his argumentation. 


\section{The definition of foreign}

One of Knud Knudsen's greatest works was his monumental dictionary Unorsk og norsk eller fremmedords avløsing (Non-Norwegian and Norwegian or the replacement of foreign words), which, in his own words, was meant to "be for the writing (and speaking) and help them in many instances to be able to avoid the foreign, that is to replace [...] nonNorwegian [words] with Norwegian; foreign with domestic". ${ }^{1}$ (Knudsen, 1881, p. III) ${ }^{2}$

Both the title of the dictionary and this quote indicates a typical purist logic, focusing on foreign versus domestic vocabulary, where the latter is regarded purer and therefor superior. Typical for Knudsen, however, is the tendency of being somewhat inconsistent in his argumentation, or at least having several layers in his texts that do not necessarily harmonize. In this particular foreword, there is a tension between the supposed opposition towards foreign vocabulary, and the reasoning behind this opposition.

Immediately after his explanation of why he made his "replacement dictionary" as quoted above, he goes on to clarify his view in more depth (with my underlining):

To get rid of all these foreign words is not an option. Some of them are understood, and partly being used, by all classes of the people, and are therefor not really foreign - others cannot be replaced by domestic words, at least not yet (Knudsen, 1881, p. IV). ${ }^{3}$

It is clear that the term foreign needs to be discussed in order to map Knudsen's argumentation. To him this term does not seem to be connected, at least not exclusively, to national borders or etymological connections. In this quote, and also elsewhere in his vast number of publications, what is regarded unwanted, or un-pure, is what is unintelligible.

In an almost identical quote, Ivar Aasen writes:

To keep the language completely free from all foreign words will probably not be possible ever, and it is actually not necessary as long as the imported words fit neatly together with domestic forms, so that the people do not find them difficult and the words do not disrupt the rules of the language. ${ }^{4}$ (Aasen, 1899, p. 118)

Here Aasen is also open for including some foreign words, but for a different reason. Imported words need to follow the rules of the domestic language, making this a structural linguistic argument (Sandøy, 2000, p. 190). When the linguistic rules of the "receiving"

1 All translations of Norwegian quotes into English are my own.

2 "...være for de skrivende (og talende) og hjælpe disse til i mangfoldige tilfælder at kunne undvære udlændingerne, altså til at avløse ("erstatte", "remplacere”) unorske [ord] med norske, udenlandske med indfødde.

$3 \mathrm{Nu}$ at skille os av med alle disse fremmede, derom er der jo ikke tale. Nogle forstås, og til dels bruges, av alle folkeklasser, og er således ikke egentlig fremmede, andre lader seg jo ikke avløse med indenlandske, i det mindste ikke endnu.

4 At holde Sproget aldeles reent for alle fremmede Ord vilde neppe nogensinde være muligt, og i Grunden kan dette heller ikke være saa ganske nødvendigt, naar kun de indførte Ord passe saavidt sammen med de hjemlige Former, at de ikke falde Folket besværlige eller forstyrrer Begrebet om Sprogets Regler. 
language make up the terms for what is accepted, there is still a notion of domestic versus foreign.

Although both arguments include a reference to the people, and therefor has a democratic aspect as well, the people in Aasen's argument should not be bothered with words that do not fit the linguistic structures that they are familiar with; whereas the people in Knudsen's argument should not be bothered with words that they do not understand. Knudsen is a teacher and a pedagogue, and he surely argues like one.

The term foreign can of course mean different things in everyday speech. In Collins English Dictionary, both "involving, located in or coming from another country" and "not pertinent or related" are listed as meanings (www.dictionary.com, 2016). The term used by both Knudsen and Aasen is "fremmed", which can be translated with either foreign or strange, or more generally: un-familiar. Therefor, the word fremmed itself is ambiguous, and it is clearly used in (at least) two different ways in the $19^{\text {th }}$ century Norwegian language debate.

This does not mean, however, that either of the two men uses the word foreign consistently according to one definition or the other. Aasen argues for example in a similar way to Knudsen; that the words which have been used extensively in Norway are no longer strange to the Norwegian people:

These foreign words are no more foreign to us than to the Danish. Such words have been imposed in our books for such a long time that we have had to learn them; we have had to learn a whole bunch of them beside our own language, and if this is considered «keeping up with culture» then Norwegian has also been keeping up. What is stopping us now from using such words? ${ }^{5}$ (Aasen, 2013)

Lars S. Vikør has given an overview of various principles for language planning. He underlines what we see here, namely that the language view of a person or an organization is normally a combination of various principles and we hardly ever find a person who exclusively cultivates one principle (Vikør, 1994, p. 143). It is however normal to let one principle be the main reference point.

\section{Intelligibility as an instrumental argument}

The intelligibility argument can be categorized as instrumental (or pragmatic) and part of an overall rational orientation (Thomas, 1991, p. 49). Such an orientation "emphasises the instrumental character of language and evaluates linguistic means according to the criterion of functional adequacy, effectivity, economy and the binding force of collective norms" (Thomas, 1991, p. 36). According to Thomas, Aasen can also be placed in the

5 Desse framande Ordi ero inkje stort meir framande fyre oss en fyre dei Danske. Det hever so lenge voret buldrat paa med slike Ord i alle vaare Bøker, at me eingong maatte læra deim; me hava lært ei heil Mukka av deim jamsides med vaart eiget Maal, og naar dette skal heita "at fylgja med Kulturen", so hever Norsken ogso fylgt med. Kvat hindrar oss no ifraa at bruka slike Ord i Norsken? 
same category, i.e. using an intelligibility argument (Thomas is referring to Gerdener's book Der Purismus im Nynorsk: Historische Entwicklung und heutiger Sprachgebrauch from 1986). The difference between them however, is that for Knudsen the intelligibility argument was the most important one. For him the language was primarily a means of communication, and as a teacher, the pedagogical barriers that the language represented were simply something that had to be solved.

Aasen does not go as far as Knudsen in the use of pragmatic arguments, but there were others that shared such an instrumental view on the language. There are several examples of purism based on functional arguments both in Europe and in the rest of the world. One example is the English writer William Barnes who similar to Knudsen was interested in orthography (but on the other hand - similar to Aasen - was very concerned with preserving various dialects, especially his own) and who used intelligibility as part of his argumentation for reforming the English language. In an article on English Purism by Jonathan Roper, we find this quote from Barnes:

...half a country congregation understand but half the sermon, and youth but a quarter of what they read [...] It causes great toil and obstructions to the teacher of youth, and keeps pupils learning words, when he should be learning facts (Roper, 2012)

It is of course not surprising that elements from the age of enlightenment still can be found in $19^{\text {th }}$ century argumentation on such pedagogical central elements as language: The language needs to be functional in order to do its job as an educational tool. An adoption between different language families is acceptable if the result is a more functional language, according to Knudsen - a reasoning that is in sharp contrast to the typical purist desire to keep the language clean from other "families".

This logic also means that unwanted elements can easily be turned into wanted elements. If a linguistic element enters into a language, where it has not previously been used, it is unwanted and "un-pure" as long as it is not understood and not in general use. If one or both of those conditions change, however, it will in theory go from being marked as foreign to not being marked as foreign. One does not need to know a lot about language change to see that this is a very realistic and pragmatic way of dealing with actual changes in vocabulary.

\section{Can this really be called purism?}

This might seem as being very mild and open-minded towards foreign words in general, and one may wonder why Knudsen is considered to be a purist at all. Let him modify this image himself:

My Norwegianness in the vocabulary is still more exclusive than inclusive, more negative than positive. Thousands of foreign words, not only Greek and Latin, but also German (though not all of them), are mercilessly «left outside», while hardly ten new Norwegian words have been 
included which have not already, at least once or twice, been used by others before. ${ }^{6}$ (Knudsen, 1867, p. VII)

This was written in 1867, 14 years before the dictionary was published, and it might seem that he was more strict against foreign words in 1867 than in 1881. On the other hand, the phrasing "thousands of foreign words have been excluded" and "replacement of all foreign words is not an option" can actually mean the same thing when it comes to actual practice: many words are excluded, some are included.

The perspective of exclusion/inclusion is not the most interesting one according to Knudsen. In another quote from his quite voluminous foreword in the dictionary he says:

During my work it became more and more clear to me, that one should work not only, at least not exclusively, against foreign elements in our vocabulary, but rather towards something - towards making the nearest, domestic vocabulary more easily accessible then has been the case so far. ${ }^{7}$ (Knudsen, 1881, p. IV)

In a much quoted definition of purism by Annamalai the key word is not only closure towards foreign elements, but also opening towards familiar elements, here copied from Brunstads article Standard language and linguistic purism: "Purism is the opening of the native sources and closure of the non-native sources for the enrichment of language" (Brunstad, 2003, p. 53). With such a definition Knudsen would certainly be a purist, since he is eager to draw from the native Norwegian vocabulary in order to replace unintelligible foreign words.

Knudsen's strategy in this respect was clear: in order for perhaps less known Norwegian words to be accepted by the language users, the words simply needed to be seen. In a book on an otherwise unrelated topic, Knudsen quotes the Danish professor Niels Mathias Petersen (1791-1862) whom Knudsen agreed with on many subjects: "Words are like girls ready to be married, they need to be seen. No one will go looking for them if

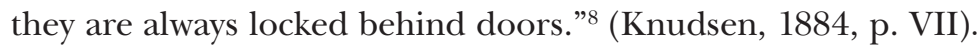

6 Min norskhet i ordforrådet er fremdeles mere utdrivende æn inlatende, mere negative æn positive. Fremmedord I tusenvis, ikke alene græske, latinske og franske, men og tyske (dog ikke alle) er uten barmhjertighet "sat udenfor", medens neppe ti nye norske er der inlat, som ikke allerede før, i det minste en og annen gang, har været brukt av andre.

7 I løbet av denne min gjerning blev det mig imidlertid mere og mere klart, at der burde stræes ikke nærmest, I alle fald ikke udelukkende, mod det fremmede I vort ordforråd, men snarere for noget, for at omtrent hele det nere, indenlandske forråd kunde blive lettere tilgjængeligt, end det hidtil var tilfældet

8 Det gaar med Ord som med gifteferdige piker [...] de maa lade sig se. Ingen søger dem op, naar de bestandig ere under Laas og Lukke 


\title{
Intelligibility in a wider perspective
}

To Knudsen, what is intelligible or not forms his opinion on most topics. In spelling: the orthophonic writing that he was a strong advocate for makes the written language easier to understand, according to Knudsen. In school politics: Latin as a subject in school was useless since the point of literature was to "translate into real life [something that] the domestic language and the domestic literature could do in a completely different scale" (Knudsen, 1884, p. 23). ${ }^{9}$ This focus on intelligibility has a strong democratic impact intelligible means accessible.

Intelligibility was also an important factor in his criticism of Landsmål. Knudsen argued that Landsmål was not easily understandable for the Norwegian people and that they understood Danish better because they had already met that language in school and in dealings with officials. Claiming to know what the Norwegian people actually thinks and understands is of course quite ambitious. Knudsen built his claimed knowledge on meetings with people across the country during walks that he made every summer for about 50 (!) years. A good illustration of one of these meetings, can be found in this story from 1867 when he meets a soldier who shares his food with him:

\begin{abstract}
We spoke together about this and that, and he turned out to be a sensible man. I asked him, among other things, if he knew about Vinje, Dølen, and his Landsmål. Yes, he had heard about it. But do you really understand it, so that it can have some real progress? Well yes, he said, but we understand Danish (Bokmål) better. ${ }^{10}$ (Knudsen, 1987, p. 391)
\end{abstract}

Knudsen often uses the term commonality (almuen) when he refers to the beneficiaries of his work. He does not often define or describe this group of people - but on the other hand he very often depicts the opposite category: what he calls the educated (dannede). They are, in his opinion, very often ignorant, conservative and most importantly: not in touch with the real people (unlike himself of course). One example from a trip he made in the summer of 1863 :

I asked on Tjelde, where I found Bang's magazine, if anyone there had unsubscribed from that magazine because of its so-called «new language» the previous year. It was of course in 1862 that Bang introduced the so-called hard consonants, p-t-k, for the Danish b-d-g after the vowel in accented syllables [...]. But the boy I talked to, by the way a very clever guy, did not even understand what I meant. And when I had explained it to him, he said that the farmer took the spelling as it was, without any fuss. That statement confirms what I so often have said; that it is "the educated" who use the common people as an argument against all

9 ...uden den Magt til at gaa med over i Livet, som det hjemlige Sprog og den hjemlige Literatur i en ganske anden Grad maa eie

10 Vi talte sammen om et og annet, og han viste sig å være en forstandig man. Bl.a. spurte jeg ham, om han kjænte Vinje, Dølen, og hans Landsmaal. Ja, det gjorde han da. Om de da forstod det, så det var nogen virkelig fræmgang i det. Å jau, sa' han, men me forstænd dansk (Bogsproget) bæ're (bedre) 
"new-spellers" and other troublemakers. The concern for their well-being is therefore only deceit, only hypocrisy...11 (Knudsen, Reiseminner Hefte III, 1983, p. 298)

This, and other similar stories, indicate that Knudsen was sincerely concerned about what he called the common people, and his insisting on creating an intelligible language makes sense in this context: He wanted to make education and knowledge accessible for these people.

\section{Other aspects of Knudsen's purism}

In this article the main emphasis has been on intelligibility as a part of Knudsen's rational orientation. But there are two more factors that I will briefly mention, adding to the impression that Knudsen's purism does not fit the standard definition of the term.

The first one has to do with an expression often quoted in connection with Knudsen, namely "gradvishetens vei" (the road of gradual change). This kind of logic is in sharp contrast to the black-white imagery that is often associated with purism: If something is considered un-pure, it should naturally be kept away from what is pure, and not gradually be included - if the two are mixed, the result is grey, i.e. no longer pure.

The gradual change in Knudsen's case is however not about including un-pure, or in his case non-understandable, elements, into something that is already pure. This leads us to the second factor: What he advocates is to gradually change the un-pure (Danish) into something pure (Norwegian high class variety). Again: Knudsen is not a typical purist. This strategy is hardly covered by Thomas' definition of purism, since this is an attitude for what is pure, not against what is un-pure.

This strategy made him the target of attacks from both sides in the Norwegian $19^{\text {th }}$ century language debate. The users of the Danish language (the elite) accused him of ruining the Danish language, i.e. he was criticized by Danish purists. The followers of Landsmål claimed that his strategy was un-national, and that it was impossible to take a complete structure like the Danish language and only change bits and pieces.

\section{Conclusion}

There is a lot that should be said about Knudsen's purism and his argumentation. The goal here was to point out a few factors that make the purism of Knudsen somewhat different from the purism as formulated by for example Aasen. Firstly, what is unwanted

11 Jeg spurte på Tjelde, dær jeg fant Bangs blad, om nogen dær hadde sagt det op på grun av hans så kalte "nye Sprog" året i forvejen. Det var måvite 1862, Bang inførte de så kalte hårde medlyd, p-t-k for bokens danske b-d-g efter selvlyden i tonelagte stavelser (skape-bøte-koke). Men gutten, jeg talte med, for resten en nokså forstandig fyr, skjønte ikke engang, hvad jeg mente. Og da jeg så hadde grejet det ut for ham, sa han, at bonden tok skrivemåten, som han forefant den, uten å gjøre opstyr. Den ytring stadfæster, hva jeg så tidt har sagt, at det ær "de dannede", som sætter almuen op og bruker den imot alle "nystavere" og andre urostiftere. Omsorgen for dens vel ær for så vidt bare skrømt, bare "Hykleri" 
and/or un-pure in Knudsen's way of thinking is what is unintelligible to the common people. This seems to be more important than the linguistic genealogical origin of a word, and it calls for a need to specify the word foreign used in many definitions of purism. Secondly, the strategy of gradual change does not harmonize with an imagery of pure/un-pure. And thirdly, his point of departure was in the un-pure. He starts with a language that needs to be "cleansed" and the goal is to gradually introduce "pure" elements until the language is understandable and practical for all users of the language.

His vast number of suggestions for Norwegian replacements of foreign words did not result in many actual substitutions. However, in retrospect his way of thinking did result in a more Norwegian Danish than was originally the case. It is of course impossible to imagine what his reaction to today's Bokmål would have been, but he might have responded like he did when asked about the point of changing something gradually one tiny step at a time: "Crumbles are also bread, and many streams make a big river" (Knudsen, 1867, p. VII).

\section{References}

AASEN, I. (1899): Norsk grammatik. Christiania: Cammermeyer.

AASEN, I. (2013, March 12): Aasen tunet. Historiske tekstar. Hentet fra Aasentunet: http:/ www.aasentunet.no/iaa/no/sprak/historiske_tekstar/1851-1870/1859+Minningar+fraa+maalstriden. $+04+\mathrm{Fj}$ orde+r\%C3\%B8da.b7C_wJnWZn.ips

BRUNSTAD, E. (2003, January): Standard language and linguistic purism. Sociolinguistica, pp. $52-70$.

GERDENER, W. (1986): Der Purismus im Nynorsk. Münster: Hölker.

HYVIK, J. J. (2016): Tokulturlera $i$ norsk historie. Viborg: Det norske samlaget.

KNUDSEN, K. (1867): Det norske målstrev. Kristiania: Brøgger \& Christie.

KNUDSEN, K. (1881): Unorsk og norsk eller fremmedords avløsning. Kristiania: Alb. Cammermeyer.

KNUDSEN, K. (1884): Latinskole uten latin. Kristiania: A.W.Brøgger.

KNUDSEN, K. (1983): Reiseminner Hefte III. Oslo: Det norske samlaget.

KNUDSEN, K. (1987): Reiseminner Hefte IV 1864-1868. Bergen: Det norske samlaget.

ROPER, J. (2012): English Purism. Hentet fra www.academia.edu: https://www.academia. edu/1543384/English_Purisms

SANDØY, H. (2000): Lånte fjører eller bunad. Om importord $i$ norsk. Oslo: LNU og Cappelens Forlag. THOMAS, G. (1991): Linguistic Purism. New York: Longman.

VIKØR, L. S. (1994): Språkplanlegging. Prinsipp og praksis. Oslo: Novus forlag. www.dictionary.com. (2016, 06 14). From http://www.dictionary.com/browse/foreign?s=t

\section{Evy Beate Tveter / evy.b.tveter@hit.no}

Lecturer in Nordic linguistics, University College of Southeast Norway

HSN - campus Bø, IKH - Hallvard Eikas plass 1, 3800 Bø i Telemark, Norway 
